УДК 378.147:81'243

DOI: $10.24144 / 2524-0609.2021 .49 .51-56$

Дроздова Вероніка Вячеславівна

кандидат педагогічних наук, доцент кафедра іноземних мов

Хмельницький національний університет, м.Хмельницький, Україна ehorova@ukr.net

http://orcid.org/0000-0002-2367-8784

Рудніцька Катерина Валеріївна

кандидат педагогічних наук, доцент кафедра іноземних мов

Хмельницький національний університет, м.Хмельницький, Україна karudik29@gmail.com

http://orcid.org/0000-0002-9644-8226

\title{
СТРУКТУРА ПРОФЕСІЙНОЇ ІНШОМОВНОЇ КОМПЕТЕНТНОСТІ МАЙБУТНЬОГО ФАХІВЦЯ
}

Анотація. Стаття присвячена дослідженню змісту та структурних компонентів професійної іншомовної компетентності майбутнього фахівця. Встановлено, що питання щодо професійної іншомовної компетентності, іiі структури ще не є достатньо висвітленим. Зазначено, що підготовка майбутнього фахівця з високим рівнем володіння іноземною мовою для здійснення професійної діяльності стає нагальною потребою сучасного світу, саме тому, формування професійної іншомовної компетентності майбутнього фахівця в ЗВО є одним із стратегічних напрямів реформування системи освіти в Україні, що зумовлює актуальність наукової розвідки. Мета статті полягає у розкритті змісту та особливостей структурних компонентів професійної іншомовної компетентності майбутнього фахівця. Для досягнення мети були застосовані теоретичні методи дослідження 3 метою розуміння проблеми та виявлення труднощів, пов'язаних з вивченням іноземної мови, мотивації щодо вивчення іноземної мови в контексті іії застосування у майбутній професійній діяльності. Виявлено, що процес формування професійної іншомовної компетентності майбутніх фахівців $є$ складним і багатоетапним та передбачає оволодіння багатьма видами компетенцій. Обгрунтовано зміст та структурні компоненти професійної іншомовної компетентності майбутніх фахівців, а саме: мотиваційний, когнітивний, діяльнісний та рефлексивний, які забезпечують умотивованість і цілеспрямованість, осмисленість і цілісність, ефективність і результативність дій щодо досягнення мети комунікативної діяльності.

Ключові слова: заклади вищої освіти; компетенція; компонент; майбутній фахівець; професійна підготовка; професійна іншомовна компетентність.

Вступ. Світові тенденції сьогодення, пов'язані 3 процесами глобалізації суспільного, економічного, політичного та освітнього простору, змінюють вимоги до підготовки фахівців різних спеціальностей. Окрім високого професійного рівня, сучасний фахівець 3 вищою освітою повинен володіти високим рівнем мовної і іншомовної компетентності для здійснення успішної професійної діяльності.

Однак практика показує, що недоліки, характерні для сучасного процесу підготовки фахівців у закладах вищої освіти, виражаються в тому, що більшість випускників за рівнем професійної підготовки не відповідають вимогам роботодавців. Цей висновок багаторазово підтверджений результатами опитувань керівників підприємств, приватних фірм, установ та кадрових служб. 3 цієї ж причини випускники самі нерідко відмовляються від працевлаштування за отриманою спеціальністю.

Таким чином, реформування вищої школи України в контексті Болонського процесу зумовлює необхідність удосконалення й підвищення рівня якості освіти, зокрема мовної освіти, оскільки без володіння студентом принаймні однією іноземною мовою неможливо забезпечити виконання основних положень Болонської декларації: адаптація до норм і стандартів європейського освітнього простору, мобільність, професійна конкуренція матимуть місце лише за умови знання випускниками університетів іноземної мови та сформованих навичок комунікативної поведінки у відповідних ситуаціях академічного, професійного та повсякденного спілкування [1].

Актуальність. Як зазначає С.Квіт «...не можна уявити собі бакалавра чи магістра сучасного уні-

верситету без володіння англійською мовою саме на професійному рівні. Такі результати навчання мають стати складниками стандартів вищої освіти» [2]. Саме тому підготовка майбутнього фахівця будь-якого профілю, який вільно володіє іноземною мовою на рівні, що є достатнім для здійснення професійної взаємодії у міжкультурному просторі, стає нагальною потребою сучасного світу. В свою чергу, імплементація компетентістного підходу щодо формування професійної іншомовної компетентності майбутнього фахівця в ЗВО є одним із стратегічних напрямів реформування системи освіти в Україні. Таким чином, дослідження питання щодо змісту та структури професійної іншомовної компетентності майбутнього фахівця, яка відповідає вимогам Загальноєвропейських рекомендацій 3 мовної освіти, зумовлює актуальність нашої наукової розвідки.

Проте, ми спостерігаємо певне протиріччя між вимогами сучасного суспільства в умовах глобалізації та наявним рівнем професійної іншомовної компетентності випускників закладів вищої освіти.

Аналіз останніх досліджень і публікацій. Проблема формування професійної іншомовної компетентності майбутніх фахівців знайшла відображення у працях вітчизняних та зарубіжних науковців при дослідженні та вирішенні певних питань, а саме: проблеми професійної компетентності фахівця (Л.Васильченко, О.Гура, С.Демченко, Е.Зеєр та ін.); формування та розвитку іншомовної комунікативної компетентності (О. Волобуєва, Г.Китайгородська, Л.Лисак, О.Тарнапольський, R.Ellis та ін.); розуміння сутності іншомовної компетентності (Л.Нежведилова, О.Самойлова, В.Теніщева, 
А.Холлідей та ін.); особливостей комунікативної компетенції та компетентності (А.Алексюк, М.Барна, Н.Бібік, В.Бондар, В.Буряк, І.Виноградова та ін.); зміста та структури комунікативної компетентності фахівців (Л.Бахман, І.Зимня, М.Свейн та ін.).

Проте, проведений аналіз джерел свідчить про те, що, незважаючи на значний науковий інтерес до проблем професійної підготовки фахівців у закладах вищої освіти, питання щодо професійної іншомовної компетентності, іiі структури ще не є достатньо дослідженим.

Мета статті - розкрити зміст та особливості структури професійної іншомовної компетентності майбутнього фахівця. Для досягнення мети нами були використані такі методи дослідження: теоретичні - аналіз наукових джерел, педагогічної, та психологічної літератури, навчально-методичних матеріалів й посібників, порівняння з метою виявлення ступені досліджуваності зазначеної теми наукової розвідки; емпіричні - узагальнення педагогічного досвіду, використано з метою виявлення труднощів, пов'язаних з вивченням іноземної мови, мотивації щодо вивчення іноземної мови в контексті їі застосування у майбутній професійній діяльності.

Виклад основного матеріалу. Покращення якості професійної іншомовної підготовки майбутніх фахівців продиктовано необхідністю розробки нових підходів до навчання іноземних мов у закладах вищої освіти, розвитком професійної іншомовної компетентності, успішне засвоєння якої дозволить їм побудувати базу свого особистого та соціального життя 3 практичними навичками та вміннями реалізовувати їх у професійній діяльності.

Як наголошує Л.Артюшкіна, «професійна мовна компетентність - це засвоєння, усвідомлення мовних норм, що склалися історично у фонетиці, лексиці, граматиці, орфоепії, семантиці, стилістиці, та адекватне їх застосування в будь-якій людській діяльності у процесі використання певної мови. Це інтегративне явище, яке охоплює спеціальні здібності, знання навички, уміння, стратегії і тактики мовної поведінки, установки для успішної мовленнєвої діяльності в конкретних умовах спілкування. Такий вид компетентності властивий високоосвіченій та культурній людині. Це вміння адекватно і доречно користуватися мовою в конкретних ситуаціях (висловлювати свої думки, бажання, наміри, прохання тощо), використовувати для цього як мовні, так і позамовні (міміка, жести, рухи) та інтонаційні засоби увиразнення мовлення» [3].

Професійна іншомовна компетентність - це комплекс знань, умінь та навичок, компетенцій, що $\epsilon$ складовими іншомовної професійної компетентності. Високий рівень сформованості професійної іншомовної компетентності передбачає вільне володіння іноземною мовою, здатність використовувати знання в професійній або іншій комунікативній ситуації [4].

Згідно із Загальноєвропейськими Рекомендаціями 3 мовної освіти [5] існує шість рівнів володіння мовою, які були розроблені Асоціацією Мовних Експертів ALTE (The Association of Language Testers in Europe): 1-й рівень (Breakthrough) - рівень початкової мовної підготовки; 2-й рівень (Waystage); 3-й рівень (Threshold); 4-й рівень (Vantage) - володіння мовою, що характеризується адекватною реакцією у всіх найбільш поширених ситуаціях; 5-й рівень (Effective Operational Proficiency) відповідає стандарту, визначеному для студентів, що бажають навчатися у вищих навчальних закладах Британії та Франціі; 6-й рівень (Mastery) - рівень володіння мовою досконало.
Американські вчені переосмислили і модифікували рівні комунікатівної компетенції з урахуванням нової парадигми освіти в нашій країні, і ними було виділено шість рівнів комунікативної компетентності.

I - початковий рівень володіння основними видами мовленнєвої діяльності (Starter, Beginner);

II - середній (елементарний рівень володіння комунікативною компетентністю) (Elementary);

III - 3 просунутий рівень володіння комунікативною компетентністю (Pre-intermediate);

IV - високий рівень комунікативної компетентності (може бути досягнутий у школах 3 поглибленим вивченням іноземних мов) (Intermediate);

$\mathrm{V}$ - професійно-достатній (співвідноситься більшою мірою 3 навчанням у немовних 3ВО) (Upper- Intermediate);

VI - вищий, наближений до рівня комунікативної компетентності освіченого носія мови (співвідноситься 3 навчанням у мовних закладах вищої освіти і підготовкою фахівців у галузі іноземних мов) (Advanced) [5].

Протягом своєї «мовної кар'єри» майбутнім фахівцям не слід забувати, що процес вивчення мови $\epsilon$ безперервним та індивідуальним. Немає двох користувачів мови, чи то носіїв, чи іноземців, що іїі вивчають, які б мали абсолютно однакові компетенції або розвивали їх однаковим шляхом. Будь-яка спроба встановити «рівні» володіння мовою матиме довільний характер у будь-якій галузі знань чи вмінь.

Процес формування професійної іншомовної компетентності майбутніх фахівців $\epsilon$ складним i багатоетапним, що передбачає оволодіння багатьма видами компетенцій. На основі аналізу наукових досліджень вітчизняних та зарубіжних вчених ми визначили компоненти професійної іншомовної компетентності майбутніх фахівців: мотиваиійний, когнітивний, діяльнісний та рефлексивний. Вони забезпечують умотивованість і цілеспрямованість, осмисленість і цілісність, ефективність і результативність дій щодо досягнення мети комунікативної діяльності.

Мотивація сприяє не лише позитивному ставленню студента до навчально-пізнавального процесу, а й визначає його готовність до професійної діяльності в майбутньому [6, с.150]. Мотиваційному аспекту присвячені дослідження А.Маслоу, А.Маркової, Є.Клімова, А.Леонтьєва, І.Зимньої та багатьох інших педагогів, філософів, психологів.

Психологи стверджують, що мотивацію не можна спостерігати безпосередньо, але вона може бути виявлена на основі деяких когнітивних, поведінкових й емоційних показників. Вона виявляється у прагненні докладати зусиль й досягати певних результатів у значущій та важливій сфері. Поняття «мотивація» $є$ конструктором, яке використовується для опису й пояснення причин поведінки людини, iii спрямованості та механізмів здійснення. Завдяки мотивації студенти усвідомлюють важливість знань для успішного оволодіння майбутньою професією, їх необхідності для орієнтування в різноманітних ситуаціях професійної діяльності, що в свою чергу викликає потребу в оволодінні професійними уміннями та навичками. Як стверджує Гордєєва, «успішна професійна діяльність вимагає від майбутнього фахівця важливих мотиваційних характеристик, таких як: інтерес до справи, віра у свої здібності, адекватно реагувати на невдачі, уміння справлятися 3 труднощами» [7].

Методика навчання іноземної мови трактує термін «комунікативна мотивація» як явище, в основі якого лежить і потреба в спілкуванні як така, що 
властива людині як соціальній істоті, і потреба в здійсненні конкретного мовного вчинку, потреба «втрутитись» у певну мовну ситуацію. Обидва ці види потреби взаємопов'язані, проте неоднозначні при використанні їх у навчанні. Перший з них відносять до загальної комунікативної мотивації, рівень якої часто не залежить від організації навчального процесу, однак він є фоном для другого виду - ситуативної мотивації, рівень якої на вирішальному етапі визначається тим, як ми навчаємо, як створюємо мовні ситуації, який використовуємо матеріал.

Для того, щоб мотивація була високою, студентам потрібне усвідомлення життєвої необхідності володіння іноземною мовою в сучасних умовах, яке, за наявності зрозумілих мотивів, приведе до жаги у набутті, поглибленні знань, потреби у їх засвоєнні, прагнення розширити кругозір. Саме тому мовну діяльність потрібно наблизити до реальної комунікації, що надасть можливість використовувати мову як засіб спілкування. Адже, як показують дослідження, «найбільший вплив на академічні успіхи здійснює пізнавальна потреба в поєднанні з високою потребою у досягненнях» [8].

Отже, мотиваційний компонент визначає ставлення студентів до навчальної діяльності, іiї змісту, способів виконання і результатів цієї діяльності. Цей компонент включає мотиви, потреби у професійному навчанні, вдосконаленні, саморозвитку, ціннісні установки актуалізації у професійній діяльності.

Когнітивний компонент, пов'язаний 3 такими категоріями, як знання, мислення й процеси розуміння, задіяний у ході мовного навчання й залучення студента до культури народу - носія мови. Когнітивний розвиток пов'язаний з формуванням у студентів навичок гнучко використовувати різні види інформації, активно інтерпретувати їх. Відзначимо, що процес оволодіння засобами професійного спілкування - це процес не механічного вироблення навичок і вмінь, він має активний, творчий і когнітивний характер. При цьому підкреслимо, що мова йде про оволодіння студентами різними стратегіями і техніками навчання й спілкування відповідно до конкретного етапу його особистісного й іншомовного розвитку.

Виходячи з вищесказаного, відзначимо, що процес оволодіння здатністю до іншомовної комунікації повинен формувати у студентів мовну картину світу, аналогічну тій, якою володіє носій мови - його одноліток в іншій країні, а також розуміння відповідних обумовлених культурою специфічних характеристик представника «іншої соціокультурної спільноти». Когнітивний компонент включає лінгвістичну, предметну, соиіокультурну та інформаційно-аналітичну компетениіі.

Ми вважаємо, що лінгвістична компетенція є базовою у когнітивному компоненті професійної іншомовної компетентності майбутнього фахівця, оскільки відповідає за мовну сферу та складається 3 лексичних, фонетичних, граматичних та синтаксичних знань. На основі здобутих знань формується уміння використовувати складні лексико-граматичні конструкції, коректно будувати висловлювання іноземною мовою, розуміти значеннєві відрізки мовлення, аналізувати та оцінювати зміст отриманого повідомлення чи тексту, правильно писати та інтерпретувати тексти. Зазначене вище формується та розвивається в процесі комунікативної діяльності.

Предметна компетенція тісно пов'язана з обсягом знань про предмет комунікації. Принцип цієї компетенції полягає у можливості застосування предметних знань у мовній структурі.

Соціокультурна компетенція характеризується знанням про звичаї, культуру, історію, географію, специфіку мови, норми комунікативної поведінки, про національний характер, суспільно-державний устрій, особливості побуту, традиції, освіту країни мова якої вивчається. Найважливіші принципи цього компонента - 1) неподільність функціонування мови; 2) усвідомлення майбутнім фахівцем цінності спілкування, що спонукає зіграти певну соціальну роль.

Під час формування соціокультурної компетенції розвивається здатність студентів сприймати, аналізувати, оцінювати й використовувати одержані відомості про країну, мова якої вивчається через ознайомлення з історією і розвитком її мови, з'ясовується: приналежність споріднених мов до певної мовної групи, сім’ї; здатність сприймати мову в ії культуроносній функції, з національно-культурними особливостями; поєднується знання мовних одиниць 3 національно-культурним компонентом семантики i ïx використання відповідно до соціально-мовленнєвих ситуацій [9].

Згідно Загальноєвропейських Рекомендацій 3 мовної освіти, під час формування соціокультурної компетенції повинні досліджуватися маркери соціальних відносин (привітання, прощання, форми звертання, подяки тощо), правила ввічливості, вирази народної мудрості, відмінності між варіантами мови під час вживання їі у різних контекстах, діалектні та акцентні розбіжності, наступним етапом $\epsilon$ використання цих знань у процесі спілкування [10].

Інформаційно-аналітична компетениія передбачає теоретичні знання 3 предмета, уміння й навички оперування інформацією, інформаційними об'єктами, включає знання способів отримання інформації та іiі передачі, навички вдосконалення професійних знань і умінь, визначає вміння працювати 3 різними джерелами (друкованими, електронними, Інтернет) професійно-значущої іншомовної інформації (пошук, збір, зберігання, обробка) і критично оцінювати їх (розуміння, застосування, аналіз, синтез, оцінка) у рамках здійснення професійних обов'язків іноземною мовою. Рівень розвитку цього компонента визначається повнотою, глибиною, системністю знань у предметній галузі.

Діяльнісний компонент характеризує готовність майбутнього фахівця до здійснення ефективного професійного спілкування, та складається з комунікативної та стратегічної компетениій. Комунікативна компетенція включає сукупність знань, умінь і навичок, що забезпечують ефективний комунікативний процес, адекватний меті, сферам і умовам комунікації; вміння прогнозувати іншомовний комунікативний акт одночасно рідною мовою та мовою партнера при обміні інформацією у певній ситуації. Основний принцип - постійна готовність до комунікації.

За словами В.Манько, сутність стратегічної компетениї̈ полягає $y$ здатності володіти стратегіями навчання та іншомовного спілкування. Безпосередньо стратегія навчання складається з системи прийомів, які сприяють оптимізації пізнавальної діяльності тих, хто навчається, та забезпечують швидке та міцне засвоєння знань, умінь й навичок. [11].

Ми погоджуємось 3 I.Мегаловою [12] і зазначаємо, що під час нашого дослідження метою вивчення мови було формування здатності студента виконувати мовленнєву діяльність за умови власного вибору і успішного застосування ефективних у конкретних умовах комунікативних стратегій.

Стратегічна компетенція - це здатність використовувати вербальні та невербальні комунікативні стратегії для запобігання або компенсації зриву в процесі спілкування, а також ефективного досягнен- 
ня його цілей, поглиблення знань мови, одержання мовленнєвого і соціального досвіду в умовах недостатньої комунікативної компетентності співрозмовників або у несприятливій мовленнєвій ситуації [11].

Стратегічна компетенція розглядається як у широкому (лінгводидактичному), так і у вузькоспеціальному (лінгвометодичному) значенні. У широкому значенні стратегічна компетенція дає можливість студентам визначати мету власної пізнавальної, навчальної діяльності, планувати свою діяльність для досягнення будь-якої мети; реалізовувати сплановані дії, розроблені стратегії та оцінювати результат власної діяльності.

У вузькоспеціальному значенні для оволодіння стратегічною компетенцією студенти повинні аналізувати мовні та позамовні поняття, явища, закономірності, порівнювати, узагальнювати їх, виділяти головні й другорядні ознаки; моделювати мовні та позамовні компоненти, уявляти й за допомогою мовних виражальних засобів описувати предмети, явища, події, робити припущення щодо способу розв'язання проблемних ситуацій, добирати докази для доведення чи спростування власних і чужих думок, позицій, аналізувати використані мовні, граматичні, конструкції, вивчати засоби мовної поведінки вчинків людей, використовувати власний досвід та критично оцінювати власні й чужі висловлювання [13].

Отже, діяльнісний компонент виявляється у застосуванні комунікативних знань у навчально-професійному спілкуванні; вмінні налагоджувати контакти 3 різними людьми у професійній діяльності; вміння відчувати і підтримувати зворотний зв'язок у спілкуванні; вмінні чітко й емоційно виражати свої думки й почуття; вмінні логічно, зв'язно будувати мовлення, вести дискусію, давати аргументовані відповіді на запитання; вмінні орієнтуватись у змінних умовах; у знаннях механізмів і законів комунікації; вміннях прогнозувати іншомовний комунікативний акт одночасно рідною мовою партнера в ході інформаційного обміну, у володіннях стратегією навчання і стратегією іншомовного спілкування, вміннях планувати мовне поводження й передавати інформацію в аргументованих й логічно вибудуваних висловлюваннях, співвідносити мовний вчинок 3 конкретним змістом висловлювання, в активному застосуванні інформаційно-комунікативних технологій у професійній діяльності як засобу пізнання і розвитку інформаційної культури, самовдосконалення і творчості; виявляється в умінні встановлювати міжособистісні зв'язки, вибирати оптимальний стиль спілкування у різноманітних ситуаціях, опановувати засоби вербального і невербального спілкування, комунікативні вміння, що дозволяють встановлювати контакт із співрозмовником; керувати ситуацією взаємодії з суб’єктом іншомовної комунікації.

Рефлексивний компонент передбачає оволодіння психологічною, самоосвітньою, креативною та компенсаторною компетенціями.

Психологічна компетенція являє собою потенційну здатність отримувати, переробляти і відтворювати іншомовну інформацію, що сприяє вияву загальних закономірних ознак комунікативної діяльності, передбачає оволодіння певною сумою знань про те, як улаштована мова, як ми втілюємо смисли в слова (говоримо й пишемо), як ми переходимо від прочитаного або почутого до смислу (розуміємо прочитане або почуте). Провідними ознаками цієї компетенції називають знання дії мовних/мовленнєвих механізмів людини що сприяють глибинному розумінню законів успішної комунікації.
Самоосвітня компетенція являє собою здатність підтримувати і підвищувати у процесі самоосвіти рівень володіння іноземною мовою. Основний принцип пропонованого нами компонента - сформувати особистість майбутнього фахівця, здатного до саморегуляції у сфері безперервної освіти. Зупинимося на цій компетенції детальніше, оскільки формування самоосвітньої компетенції $є$ актуальним у зв'язку 3 тим, що в сучасних умовах стрімкого розвитку науки, швидкого оновлення інформації неможливо навчити людину на все життя, важливо розвинути в ній інтерес до накопичення знань, до безперервної самоосвіти. Для формування самоосвітньої компетенції потрібно використовувати «зосереджений на студентові» (student-centered approach) підхід до навчання. Такий підхід припускає високий ступінь самостійності виконання завдань як індивідуально, так і в парах або групах, сприяє розвитку самоосвітньої компетенції майбутніх фахівців, що, в свою чергу, має велике значення для їх професійної діяльності. Загальновідомо, що головною метою самостійної роботи в плані практичного оволодіння іноземною мовою є: досягнення відповідного рівня мовної компетентності в період навчання у ЗВО, формування у випускників умінь і навичок до проведення ефективної самоосвітньої роботи над іноземною мовою після закінчення ЗВО. Однак, досвід роботи показує, що лише невелика кількість випускників підтримує необхідний рівень володіння іноземною мовою. Це можна пояснити традиційно сформованою структурою самостійної роботи, у якій основне місце займає підготовка до поточних занять, вона рідко індивідуалізована й не відповідає умовам самоосвіти після закінчення ЗВО.

Креативна компетенція полягає у здатності тих, хто навчається самостійно, переносити знання, навички та вміння у новий контекст їх використання. Креативна компетенція $є$ показником комунікативного володіння іноземною мовою на певному рівні.

Компенсаторна компетенція передбачає сформованість іншомовних знань та вмінь, які сприяють подоланню труднощів у процесі спілкування іноземною мовою 3 використанням уже відомих мовних або нелінгвістичних засобів (синонімів, антонімів, перифраза, невербальних знаків тощо), задля досягнення комунікативної мети спілкування.

Отже, рефлексивний компонент характеризується вмінням орієнтуватися в різних комунікативних ситуаціях, використовувати доречні мовні засоби для висловлення власних позицій, адекватно застосовувати невербальні засоби спілкування; бути спроможним аналізувати свою поведінку та поведінку співрозмовника, вміти переробляти й передавати іншомовну інформацію у процесі взаємодії. Зазначений нами компонент передбачає: оволодіння певною сумою знань про системну організацію мови (втілення мовних одиниць у практику), здатність того, хто навчається, підтримувати та підвищувати рівень володіння іноземною мовою, уміння використовувати набуті знання та навички у професійній діяльності. Рефлексивний компонент складається 3 самосвідомості, самооцінки, самоконтролю, розуміння власної значущості у професійному середовищі, адекватної оцінки результатів своєї діяльності та здібності до самореалізації у професійній сфері.

Висновки та перспективи подалыших досліджень. Отже, формування та розвиток професійної іншомовної компетентності майбутнього фахівця $\epsilon$ пріоритетним завданням для закладів вищої освіти. В сучасній науково-педагогічній літературі не існує єдиного тлумачення поняття та структури означено- 
го терміна. На нашу думку, професійна іншомовна компетентність майбутнього фахівця - багатокомпонентне поняття, яке уможливлює здатність останнього комунікувати у процесі іншомовного фахово зорієнтованого спілкування, і містить наступні компоненти: мотиваційний, когнітивний, діяльнісний та рефлексивний. Сутність професійної іншомовної компетентності майбутнього фахівця полягає у висо- кому професійному рівні володіння ним іноземною мовою, соціокультурними та професійними знаннями, вміннями і навичками, що дають можливість доцільно використовувати мовні знання залежно від ситуації професійного спілкування. Перспективи подальших наукових розробок полягають у дослідженні професійної іншомовної компетентності для певних спеціальностей 3ВО.

\section{Список використаної літератури}

1. Черняева Т.И., Пугачева Л.Г., Лысикова О.В. Инновационные технологии в образовании: учеб.-метод. пособие. Саратов: ГОУ ВПО «Саратовская государственная академия права», 2003. 60 с.

2. Квіт С.М. Потрібні зміни: зміст і завдання освітніх реформ. Українська правда. 2015. URL: https://www.pravda.com.ua/ articles/2015/01/27/7056516 (дата звернення 8.10.2021).

3. Ерджієс С.Е. Формування професійно-комунікативної компетентності студентів-іноземиів у проиесі фахової підготовки: автореф. дис. на здобуття наук. ступеня канд. пед. наук: 13.00.04. Одеса, 2016. 24 с.

4. Демченко Д.І. Формування професійної іншомовної компетентності майбутніх юристів у фаховій підготовиі: автореф. дис. на здобуття наук. ступеня канд. пед. наук:13.00.04. Харків, 2010. 21 с.

5. Common European Framework of Reference For Languages: Learning, Teaching, Assessment. Cambridge: Cambridge Univ. Press. 2001. 260 p.

6. Психологическое обеспечение профессиональной деятельности. Теория и практика / под ред. Г.С.Никифорова. СанктПетербург: Речь, 2001. 816 с.

7. Гордеева Т.О. Психология мотивации достижения: учебное пособие. Москва: Смысл, 2006. 332 с.

8. Орлов Ю.М. Потребностно-мотивационные факторы эффективности учебной деятельности студентов вуза: автореф. дис. на соискание ученой степени д-ра психол. наук: 19.00.07. Москва, 1984. 40 с.

9. Епихина Н.О. Обогащение языковой компетенции студента в образовательном процессе вуза: автореф. дис. на соискание ученой степени канд. пед. наук:13.00.01. Красноярск, 2001. 20 с.

10.Загальноєвропейські рекомендації з мовної освіти: вивчення, викладання, оиінювання / за ред. С.Ю.Ніколаєва. Київ: Ленвіт, 2003. 273 с.

11.Манько В.М. Дидактичні умови формування у студентів професійно-пізнавального інтересу до спеціальних дисциплін. 3б. наук. пр. Національного педагогічного університету ім. Драгоманова. 2000. Вип. 2. С. 153-161.

12.Мегалова И.А. Новейшие информаиионные и коммуникаиионные технологии формирования иноязычной компетениии в российских и зарубежнных вузах (сравнительный анализ): автореф. дис. на соискание ученой степени канд. пед. наук:13.00.01. Саратов, 2000. $20 \mathrm{c}$.

13.Хуторской А.В. Компетентностный подход в обучении: науч.-метод. пособие. Москва: Эйдос, 2013. 73 с.

\section{References}

1. Chernyaeva, T.Y., Puhacheva, L.H., \& Lysykova, O.V. (2003). Ynnovatsyonnye tekhnolohyy v obrazovanyy [Innovative technologies in education]. Saratovskaya gosudarstvennaya akademyya prava. [in Russian].

2. Kvit, S.M. (2015). Potribni zminy: zmist i zavdannya osvitnikh reform [Changes are needed: the content and objectives of educational reforms]. Ukrayins'ka pravda. https://www.pravda.com.ua/articles/2015/01/27/7056516 [in Ukrainian].

3. Erdzhiyes, S.E. (2016). Formuvannya profesiyno-komunikatyvnoyi kompetentnosti studentiv-inozemtsiv u protsesi fakhovoyi pidhotovky [Formation of professionally communicative competence of students foreigners in the process of professional training] [Extended abstract of Candidate dissertation]. K.D.Ushynskyi South-Ukrainian National Pedagogical University. [in Ukrainian].

4. Demchenko, D.I. (2010). Formuvannya profesiynoyi inshomovnoyi kompetentnosti maybutnikh yurystiv u fakhoviy pidhotovtsi [Formation of professional foreign language competence of future lawyers in professional training] [Extended abstract of Candidate dissertation]. H.Skovoroda Kharkiv National Pedagogical University. [in Ukrainian].

5. Common European Framework of Reference For Languages: Learning, Teaching, Assessment (2001). Cambridge University Press.

6. Nykyforova, H.S. (Ed.). (2001). Psykholohycheskoe obespechenye professyonal'noy deyatel'nosty. Teoryya y praktyka [Psychological support of professional activity. Theory and practice]. Rech. [in Russian].

7. Hordeeva, T.O. (2006). Psykholohyya motyvatsyy dostyzhenyya [Psychology of achievement motivation]. Smysl. [in Russian].

8. Orlov, Yu.M. (1984). Potrebnostno-motyvatsyonnye faktory éffektyvnosty uchebnoy deyatel'nosty studentov vuza [Needmotivational factors of efficiency of educational activity of students of high school] [Extended abstract of Doctoral dissertation]. Ist Moscow Order of Lenin and Order of the Red Banner of Labor Medical Institute named after I.M.Sechenov. [in Russian].

9. Epykhyna, N.O. (2001). Obohashchenye yazykovoy kompetentsyy studenta v obrazovatel'nom protsesse vuza [Enrichment of language competence of the student in the educational process of the university] [Extended abstract of Candidate dissertation]. Sibir State Technological University. [in Russian].

10.Nikolayev, S.Yu. (Ed.). (2003). Zahalnoyevropeyski rekomendatsiyi z movnoyi osvity: vyvchennya, vykladannya, otsinyuvannya [Pan-European recommendations for language education: study, teaching, evaluation]. Lenvit. [in Urainian].

11.Man'ko, V.M. (2000). Dydaktychni umovy formuvannya u studentiv profesiyno-piznaval'noho interesu do spetsial'nykh dystsyplin [Didactic conditions for the formation of students' professional and cognitive interest in special disciplines]. Zbirnyk naukovykh prats Natsional'noho pedahohichnoho universytetu im.M.Drahomanova, 2, 153-161. [in Ukrainian].

12.Mehalova, Y.A. (2000). Noveyshye ynformatsyonnye y kommunykatsyonnye tekhnolohyy formyrovanyya ynoyazychnoy kompetentsyy $v$ rossyyskykh y zarubezhnykh vuzakh (sravnytel'nyy analyz) [The latest information and communication technologies for the formation of foreign language competence in Russian and foreign universities (comparative analysis)] [Extended abstract of Candidate dissertation]. Chelyabinsk State Pedagogical University. [in Russian].

13.Khutorskoy, A.V. (2013). Competence approach in teaching: scientific method. allowance [Kompetentnostnyy podkhod v obuchenyy]. Eydos. [in Russian].

Стаття надійшла до редакції 15.10.2021 р. Стаття прийнята до друку 20.10.2021 р. 


\title{
Drozdova Veronika
}

$\mathrm{PhD}$ (in Pedagogical Sciences), Associate Professor Foreign Languages Department

Khmelnytsky National University, Khmelnytsky, Ukraine

\section{Rudnitska Kateryna}

PhD (in Pedagogical Sciences), Associate Professor

Foreign Languages Department

Khmelnytsky National University, Khmelnytsky, Ukraine

\section{THE STRUCTURE OF THE PROFESSIONAL FOREIGN LANGUAGE COMPETENCY OF A FUTURE} SPECIALIST

\begin{abstract}
The article is devoted to the study of the content and structure components of the professional foreign language competency of a future specialist. Based on the research of pedagogical, psychological and methodological sources related to the problem and practical experience, it is established that the issue of the professional foreign language competency, its structure has not been sufficiently investigated yet. It has been noted that the process of training of a future specialist to obtain a high level of foreign language for professional activities performance is becoming an urgent requirement of the modern world. Thus, the formation of the professional foreign language competency of a future specialist in higher education institutions is one of the strategic directions of reformation of the system of education in Ukraine, which determines the relevance of the scientific research. The purpose of the article is to interpret the term and define structure components of the professional foreign language competency of a future specialist. Theoretical (analysis of scientific sources, pedagogical, psychological literature, educational and methodological manuals, comparison, generalization of pedagogical experience) methods were used to research the problem and identify difficulties associated with foreign language learning, motivation to learn a foreign language in the context of its application in future professional activities. It has been revealed that the process of formation of the professional foreign language competency of a future specialist is complex and multi-stage and involves mastering many types of competences. Authors have substantiated the content and structure components of the professional foreign language competency of a future specialist, namely: motivational, cognitive, active and reflexive, which, in turn, provide motivation and purposefulness, meaningfulness and integrity, efficiency and effectiveness of actions to achieve the goal of communicative activity.
\end{abstract}

Key words: higher education institution; competence; component; future specialist; professional training; professional foreign language competency. 